\title{
Identification, characterization and hydrolase producing performance of thermophilic bacteria: geothermal hot springs in the Eastern and Southeastern Anatolia Regions of Turkey
}

\author{
Orhan Ulucay (D) Arzu Gormez $\cdot$ Cem Ozic
}

Received: 16 March 2021 / Accepted: 18 October 2021 / Published online: 15 January 2022

(C) The Author(s), under exclusive licence to Springer Nature Switzerland AG 2021

\begin{abstract}
In the last two decades, researchers have increasingly focused on the rich microorganism-based diversity of natural hot spring sources to explore the benefits of thermophiles in industrial and biotechnological fields. Within the scope of this study, a total of 83 thermophilic Bacilli strains were isolated from 7 different geothermal hot springs (at temperatures ranging between 40 and $85^{\circ} \mathrm{C}$ ) located in the Eastern and Southeastern Anatolia Regions of Turkey. The physiological, morphological, biochemical and molecular properties of the isolates were determined. As a result of the $16 \mathrm{~S}$ rRNA gene sequence analysis, 5 different species (Bacillus licheniformis, Bacillus sp., Bacillus subtilis, Geobacillus kaustophilus, and Weizmannia coagulans,) were identified. B. licheniformis
\end{abstract}

Supplementary Information The online version contains supplementary material available at https://doi.org/10.1007/ s10482-021-01678-5.

O. Ulucay $(\bowtie)$

Department of Bioengineering, Faculty of Engineering and Architecture, Kafkas University, 36100 Kars, Turkey e-mail: orhanulucay@kafkas.edu.tr

\section{A. Gormez}

Department of Molecular Biology and Genetics, Faculty of Science, Erzurum Technical University,

25050 Yakutiye, Erzurum, Turkey

C. Ozic

Department of Medical Biology, Medicine Faculty, Kafkas University, 36100 Kars, Turkey and $B$. subtilis were the most frequently encountered species among those obtained from the researched hot spring sources. Phylogenetic analysis was conducted to evaluate the phylogenetic relationships of the isolated species. The results showed that there was no significant difference between the groups and the bacteria in terms of the locations or optimum temperatures of the isolates. The bacterial isolates were screened for amylase, cellulase, lipase and protease hydrolytic enzyme activities. The hydrolytic enzyme production potentials among the isolates were identified in $68(82 \%)$ isolates for amylase, $34(41 \%)$ for cellulase, $69(83 \%)$ for lipase and $73(88 \%)$ for protease. All isolates were found to have at least one or more extracellular enzyme activities. Additionally, it was determined that 27 of the existing isolates $(32.8 \%)$ were able to produce all of the aforementioned hydrolytic enzymes.

Keywords Bacillus subtilis · Enzyme activity · Geobacillus · Hot springs · Thermophilic bacteria

\section{Introduction}

Thermophilic microorganisms can thrive in aquatic and terrestrial habitats. Examples of such environments are sugar heaps, hot springs, deep seas and volcanic regions. It is known that thermophilic 
microorganisms have a diversity that includes both bacteria and archaea, and the most frequently isolated thermophilic strains have also been reported to belong to the Bacillus genus (Abootalebi et al. 2020; Ladeira et al. 2015; Shen et al. 2021; Verma et al. 2018; Wang et al. 2006). The presence of thermophilic Bacilli has been investigated in hot springs and compost sources around the world (Yanmis et al. 2015), such as those in India (Verma et al. 2018), Iran (Abootalebi et al. 2020), Indonesia (Safitri et al. 2020), Jordan (Mohammad et al. 2017), Faisalabad (Saleh et al. 2020), Tunisia (Salem et al. 2020), Brazil (Bernardo et al. 2020), Egypt (Saeed et al. 2020), Malaysia (Msarah et al. 2020), Vietnam (Dang et al. 2018), Saudi Arabia (Al-Johani et al. 2016), South Africa (Tsotetsi et al. 2020) and Japan (Akita et al. 2017).

Turkey is one of the world's most significant countries because of its abundant thermal water reserves (Oztas Gulmus and Gormez 2020b). Hot springs in eastern and southeastern Turkey are reservoirs for natural resources that are attractive for biotechnological studies (Guven et al. 2018). Various thermophilic microbial species have been reported in many studies carried out in the Hasanabdal thermal springs (Poli et al. 2012; Savas et al. 2009; Yanmis et al. 2015), Sirnak (Derya and Ahmet 2014), Diyadin (Baltaci et al. 2017), Dargecit (Acer et al. 2015), Guclukonak (Poli et al. 2012) and Pasinler (Adiguzel et al. 2011; Oztas Gulmus and Gormez 2020b). The presence of many thermophilic Bacillus and Geobacillus species has been reported in the Pasinler and Ilica thermal spring of Erzurum by different researchers (Oztas Gulmus and Gormez 2020b; Yilmaz et al. 2016).

Geothermal hot springs generally host microorganisms that can be active and produce various enzymes under extreme conditions, depending on their environment (Hogendoorn et al. 2021; Mehta et al. 2016; Panosyan et al. 2020; Short 1998). These microorganisms attract the attention of researchers as important sources of new and high-temperature resistant enzymes such as xylanases, DNA polymerases, amylases, cellulases, chitinases, lipases, pectinases, phytases and proteases (Falcicchio et al. 2021; Lee et al. 2010; Luo et al. 2017; Msarah et al. 2020; Tango and Islam 2002). These enzymes originating from microorganisms are also frequently preferred in industrial fields. In particular, enzymes are widely used in many biotechnological fields such as food processing, medicine, molecular biology, vaccine development, genetics, renewable energy, organic synthesis and biofuel production (Eriksen 2008; Khan and Sathya 2018; Zakzeski et al. 2010).

Hot springs are some of the most important habitats for thermophilic microorganisms (Aanniz et al. 2015). At the same time, many enzymes produced by microorganisms that can survive under extreme conditions remain undiscovered (Thakur et al. 2021). Due to the need in fields such as the industry, it is necessary to isolate and investigate new genera in terms of the production of biotechnologically thermostable enzymes. In general, the production of enzymes from some bacteria such as Bacilli occurs mostly in a short time, with carbon and nitrogen sources that do not require much cost (Margaryan et al. 2018). Therefore, this study is important in terms of investigating new genera with the potential to produce thermozymes in different fields of research and biotechnology.

The present study, was aimed to isolate bacteria from 7 hot springs at high altitudes in the Eastern and Southeastern Anatolia Regions of Turkey, identify these isolates by conventional and molecular methods, determine the optimum growth conditions of the isolates and analyze their capability to produce hydrolase enzymes including amylase, cellulose, lipase and protease.

\section{Materials and methods}

Collection of biological material and isolation of bacteria

Soil/sediment, mud and water samples were collected from 7 hot springs in the Eastern and Southeastern provinces of Turkey including Agri (Diyadin, Davut and Kopru; Lat.: 39.493548, Lng.: 43.649362), Erzurum (Pasinler; Lat.: 39.978194 Lng.: 41.664286), Van (Hasanabdal; Lat.: 39.225049, Lng.: 43.388236), Siirt (Hista; Lat.: 37.707582, Lng.: 42.002020), Mardin (Dargecit; Lat.: 37.546184, Lng.: 41.720381) and Sirnak (Guclukonak; Lat.: 37.476818, Lng.: 41.939351) in August and September 2016. The locations of the different geothermal sources in this study are shown on the map in Fig. 1. Samples were collected from the shallow and muddy areas at the outlet of the hot springs in sterile capped bottles. Aluminum foil was used to cover the caps to prevent exposure to sunlight. The temperature and $\mathrm{pH}$ values 


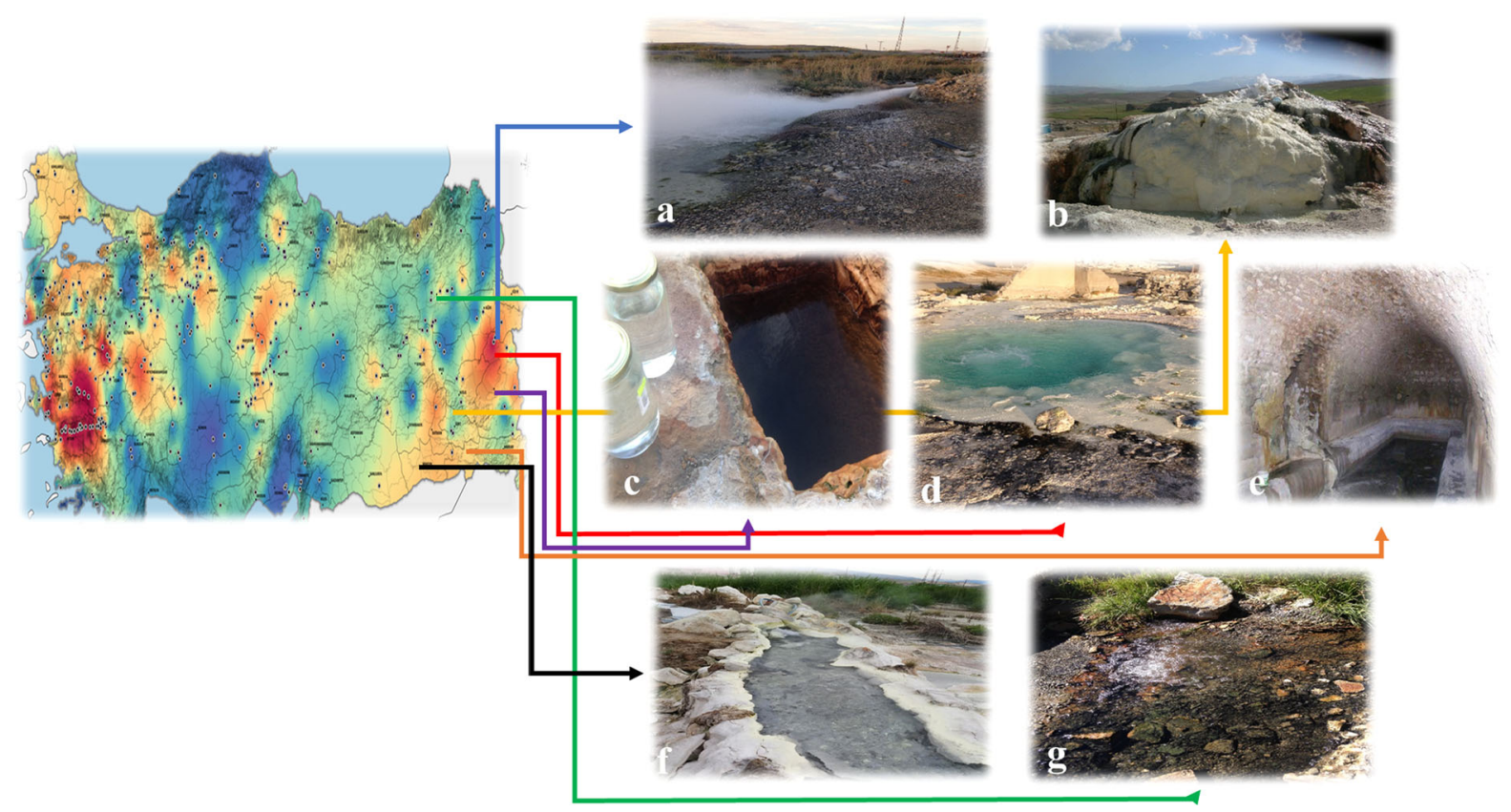

Fig. 1 Referring to the map of Turkey, hot springs under this study are indicated by arrows. Source of geothermal hot springs: a Kopru (Agri), see Supplemental Movie 1. b Hista (Siirt), c:

of the samples were measured with a pocket device (Model No. AZ 8685, Taiwan). The digital thermometer was carefully immersed at a depth of approximately $5 \mathrm{~cm}$ in the area where the samples were collected, and the readings were noted. The samples were collected at 3-m intervals. The collected samples were transferred to sterile tubes as dilutions of $10^{-1}$ $10^{-6}(0.1 \mathrm{~mL}$ sample, $0.9 \mathrm{~mL}$ physiological saline $(0.85 \mathrm{~g} \mathrm{NaCl}$ and $100 \mathrm{~mL}$ distilled water $)$. Each dilution $(0.1 \mathrm{~mL}$ sample) was transferred to petri dishes containing Luria Bertani (LB) agar (SigmaAldrich). The samples were incubated for $24-72 \mathrm{~h}$ at different temperatures $(40,55,65,70,75,85$ and $90{ }^{\circ} \mathrm{C}$ ). Different colony morphologies were selected, and these pure isolates were inoculated into the LB agar. The purified isolates were preserved in an LB medium containing $15 \%$ glycerol at $-80^{\circ} \mathrm{C}$ for subsequent analyses (Gormez et al. 2013).

Conventional characterization of bacteria

\section{Morphological properties}

The colony morphology and motility tests of the isolates were carried out by a light microscope
Hasanabdal (Van), d Davut (Agri), e Guclukonak (Sirnak), f Dargecit (Mardin), g Pasinler (Erzurum) (https://www.mta. gov.tr)

(Bestscope BS-2030t + BLC - 450). The morphological properties of the isolated bacteria were determined by Gram and endospore staining, and motility tests were carried out using standard procedures (Bernard et al. 2017).

\section{Motility}

Cell motility, morphology, shape and endospore staining properties were determined using a wet mount of freshly prepared isolates via phase contrast microscopy (Bestscope BLM-280 LCD, China) (Tsotetsi et al. 2020).

\section{Gram staining}

The bacteria were grown on the solid medium (LB agar) overnight, colonies were taken with the help of a loop, and these colonies were spread by dripping physiological saline on one side of the clean slide. The preparates were air-dried and fire-dried. They were kept in a crystal violet solution for 2 min and washed with water to allow staining. After soaking in Lugol's solution for $1 \mathrm{~min}$, the sample was washed and dried. In order to provide dechlorination in the preparate, it 
was kept for 15 to $20 \mathrm{~s}$ in $96 \%$ alcohol. It was kept waiting and washed with water again and dried. As the final processing step, the dye was removed by waiting for $30 \mathrm{~s}$ with fuchsin. After the preparates were dried on blotting paper, immersion oil was dropped, and the preparates were examined with the immersion lens under the microscope. As a result of the examinations, the blue or purple appearance of the bacteria was considered Gram-positive, and if the bacteria appeared pink, they were considered Gram-negative (Oztas Gulmus and Gormez 2020b).

\section{Endospore staining}

The bacteria were grown overnight on the solid medium (LB agar). Colonies were spread on the slide with the help of a loop. The dried preparates were first stained with carbol fuchsin for $5 \mathrm{~min}$. After washing, they were treated with $10 \%$ nitric acid for $10 \mathrm{~s}$. The preparates that were stained with methylene blue for $2 \mathrm{~min}$ were washed and dried. They were then examined under a microscope with immersion oil (Oztas Gulmus and Gormez 2020b).

\section{Physiological properties}

The physiological properties (temperature, $\mathrm{pH}$ and $\mathrm{NaCl}$ concentrations) of the isolates were tested at various stages of growth under aerobic conditions (Oztas Gulmus and Gormez 2020b). The bacterial isolates were incubated at temperatures from 40 to $90{ }^{\circ} \mathrm{C}$. The growth of the bacterial isolates was evaluated at different $\mathrm{pH}$ values (ranging from $\mathrm{pH}$ 4.0 to 12.0 , with increments of $\mathrm{pH} 1.0$ ). By adding up to $10 \% \mathrm{NaCl}(\mathrm{w} / \mathrm{v})$ to the incubation medium, the range of the $\mathrm{NaCl}$ concentrations for growth was determined. The growth of the bacteria was evaluated by measuring optical density (OD) at $600 \mathrm{~nm}$ with a spectrophotometer (GENESYS 140, Thermo Scientific). The use of various compounds at a $1 \%$ concentration (glucose, lactose, galactose, fructose, citrate, casein and starch) as a carbon source was tested.

\section{Biochemical properties}

The biochemical properties (oxidase, catalase and carbon source) of the isolates were analyzed according to the methods described by Prescott and Harley (2002) (Prescott 2002).

\section{Catalase test}

A loop sample was taken from the culture to be examined and suspended with distilled water on a slide. Then, when a loopful of $30 \% \mathrm{H}_{2} \mathrm{O}_{2}$ was added and mixed, the emergence of air bubbles showed that the test was positive.

\section{Oxidase test}

Special strips containing N, Ndimethyl-1,4phenylenediammonium dichloride were used for the oxidase test (Bactident Oxidase). The bacterial isolates taken with the loop were inoculated to the tip of the strip, and those showing color changes were determined as positive (Prescott 2002).

Molecular identification of bacteria

\section{Genomic DNA isolation}

Total genomic DNA extraction was performed by modifying Sambrook's classic phenol: chloroform: isoamyl alcohol method (Sambrook 1987), and the samples were stored at $-80{ }^{\circ} \mathrm{C}$ (Prescott and Harley 2002). The bacterial isolates were taken into a medium containing $5 \mathrm{~mL}$ of LB broth and incubated at $37{ }^{\circ} \mathrm{C}$ for $24 \mathrm{~h}$. The sample was transferred to Eppendorf tubes $(1.5 \mathrm{~mL})$ and centrifuged at $7000 \mathrm{rpm}$ for $5 \mathrm{~min}$, and then, dH2O (200 $\mu \mathrm{l}), 0.5 \mathrm{M}$ EDTA $(50 \mu \mathrm{l}), 20 \%$ sarkosyl $(10 \mu \mathrm{l})$, proteinase $\mathrm{K}(10 \mathrm{mg} / \mathrm{ml}, 10 \mu \mathrm{l}), 1 \mathrm{M}$ Tris- $\mathrm{HCl}(\mathrm{pH}: 8,10 \mu \mathrm{l})$ and $5 \mathrm{M} \mathrm{NaCl}(5 \mu \mathrm{l})$ were added. The mixture was vortexed for $5 \mathrm{~min}$ and incubated in a $65{ }^{\circ} \mathrm{C}$ water bath for $30 \mathrm{~min}$. It was vortexed every $10 \mathrm{~min}$. The same volume of phenol: chloroform: isoamyl alcohol (25:24:1) was added. The mixture was centrifuged at 13,000 rpm for $5 \mathrm{~min}$, and the supernatant was taken with the help of a pipette and transferred to a new Eppendorf tube. The phenol: chloroform: isoamyl alcohol (25:24:1) treatment was performed 3 times as described above. $3 \mathrm{M} \mathrm{NaOAc}$ up to $1 / 10$ of the supernatant volume and 2 times the volume of absolute ethanol was added to new Eppendorf tubes and incubated at $-20{ }^{\circ} \mathrm{C}$ for 1 night. At the end of the incubation time, the preparate was centrifuged at 13,000 rpm for $10 \mathrm{~min}$. The supernatant 
was removed, and the pellet was dried. $\mathrm{dH}_{2} \mathrm{O}(200 \mu \mathrm{l})$ was added to the pellet, and the pellet was dissolved. A $1 / 10$ volume of $0.3 \mathrm{M} \mathrm{NaOAc}$ and ethanol $(440 \mu \mathrm{l})$ were added to the thawed pellet and stored at $-20{ }^{\circ} \mathrm{C}$ for 1 night. At the end of the storage time, the supernatant to be centrifuged at $13,000 \mathrm{rpm}$ for $10 \mathrm{~min}$ was removed from the tube, and the pellet was left to dry. The dried pellet was dissolved with $\mathrm{dH}_{2} \mathrm{O}(100 \mu \mathrm{L})$.

\section{Amplification and sequencing of $16 S$ ribosomal RNA (16S rRNA) gene of isolates}

The PCR amplification of bacterial DNA was conducted by using a GenePro Thermal Cycler (Bioer Technology Co., Ltd) with the model code TC-E-96G. The 16S rRNA gene region of the DNA was amplified using universal primers (forward primer $27 \mathrm{~F}=5^{\prime}$ GAGTTTGATCCTGGCTCA-3'; reverse primer 1385R = 5'-CGGTGTGT[A/G] CAAGGCCC-3') (Oztas Gulmus and Gormez 2020b). The amplification reaction was carried out in a total volume of $25 \mu \mathrm{l}$ containing: 10X PCR buffer $(2.5 \mu \mathrm{L})$ (Applied Biosystems, Roche, California, USA), $25 \mu \mathrm{M}$ magnesium chloride $(2 \mu \mathrm{L}), 25 \mathrm{mM}$ dNTP $(1.5 \mu \mathrm{L}), 25 \mathrm{pmol}$ primer $27 \mathrm{~F}(2.5 \mu \mathrm{L}), 25$ pmol primer $1385 \mathrm{R}(2.5 \mu \mathrm{L})$, genomic DNA $(1 \mu \mathrm{L}), 5$ unit/ $\mu$ Taq DNA polymerase $(0.25 \mu \mathrm{L})$ (Applied Biosystems), and $\mathrm{dH}_{2} \mathrm{O}$ (12.75 $\mu \mathrm{L})$. The PCR procedure was performed under the following conditions: 1 cycle of $94{ }^{\circ} \mathrm{C}$ for 5 min., 40 cycles of $94{ }^{\circ} \mathrm{C}$ for $1 \mathrm{~min}$., $55{ }^{\circ} \mathrm{C}$ for $1 \mathrm{~min}$. and $72{ }^{\circ} \mathrm{C}$ for $1 \mathrm{~min}$., and 1 cycle of $72{ }^{\circ} \mathrm{C}$ for $5 \mathrm{~min}$. The products that were amplified by PCR were analyzed on $1 \%$ agarose gel containing ethidium bromide $(0.5 \mathrm{mg} /$ $\mathrm{ml})$ and a DNA (1 kb) molecular weight marker. The PCR products were purified and sequenced according to the methods described by many researchers (Jacobus and Gross 2015; Li et al. 1999). The band size formed by the product run in the gel was determined with the help of the appropriate marker. The band was carefully cut from the gel under UV light, and the purification process was carried out by applying the gel purification protocol of the manufacturer (Invitrogen PureLink Quick Gel Extraction Kit, Cat. no: K210012). The PCR products were sent for sequencing analysis with service procurement, and the data (sequencing results) were analyzed using GenBank (https://blast.ncbi.nlm.nih.gov/Blast.cgi). The sequencing results were uploaded onto the NCBI database. Accession numbers were obtained from the NCBI database.

\section{Phylogenetic analysis}

The phylogenetic analysis of the bacterial isolates was conducted using the neighbor-joining method and the MEGA 7 software (Oztas Gulmus and Gormez 2020b). A phylogenetic tree was created with the $16 \mathrm{~S}$ gene sequencing data of the identified bacteria, their type strains and related type strains, and outgroup to determine their evolutionary relationships. The evolutionary relationships were inferred using the Neighbor-Joining method (Saitou and Nei 1987). The optimal tree with a sum of branch length of 0.43955091 was identified. The percentage of the replicate trees in which the associated taxa clustered together in the bootstrap test (1000 replicates) was seen next to the branches (Felsenstein 1992). The tree was drawn to scale, with branch lengths in the same units as those of the evolutionary distances used to infer the phylogenetic tree. The evolutionary distances were computed by using the $p$-distance method (Nei and Kumar 2000) and are presented in units of the number of base differences per site.

\section{Screening of the enzyme activity of the bacterial isolates}

All isolates were screened for enzyme activity to reveal their ability to produce extracellular hydrolase enzymes including amylase, cellulase, lipase and protease.

\section{Amylase activity}

Amylolytic activity was examined by the use of the streak-plate technique, with a medium containing (w/ v) soluble starch $(1 \%)$, peptone $(1 \%), \mathrm{KH}_{2} \mathrm{PO}_{4}(0.5 \%)$ and agar $(1.5 \%)$ and calibrated to $\mathrm{pH}$ 7.0. The isolates producing clear zones in this medium after flooding the plates with Lugol's solution $(0.5 \% \mathrm{w} / \mathrm{v}$ and $1 \% \mathrm{w} / \mathrm{v}$ in distilled water) were considered amylolytic (Yadav et al. 2018). 


\section{Cellulase activity}

Cellulase agar was used to determine cellulase activity. The isolated bacteria were streaked on cellulose agar medium. The isolates were streaked on the agar medium [carboxymethylcellulose $(10 \mathrm{~g} / \mathrm{L})$, peptone (5 g/L), yeast (5 g/L), $\mathrm{KH}_{2} \mathrm{PO}_{4}(1 \mathrm{~g} / \mathrm{L}), \mathrm{MgSO}_{4} .7 \mathrm{H}_{2} \mathrm{O}$ $(0.2 \mathrm{~g} / \mathrm{L}), \mathrm{NaCl}(10 \mathrm{~g} / \mathrm{L})$ and agar $(15 \mathrm{~g} / \mathrm{L})]$. The cellulase activity of the isolates was determined by staining the petri dishes with Congo Red Dye (Baltaci et al. 2017).

\section{Lipase activity}

The LB medium contained $5.0 \mathrm{~g}$ peptone and $3.0 \mathrm{~g}$ beef (per liter). The $\mathrm{pH}$ of the medium was adjusted to 7 with $\mathrm{NaOH}(0.1 \mathrm{M})$. The isolation process was carried out by inoculating the samples into petri dishes in nutrient media containing tributyrin agar. The tributyrin medium contained $5.0 \mathrm{~g}$ peptone (per liter), 3.0 g yeast extract, $10 \mathrm{ml}$ tributyrin and $15 \mathrm{~g}$ agar. The culture plates were incubated and examined at 12-h intervals for 2 days. Areas with clear zone formation in the petri dishes showed activity (Ertuğrul et al. 2007).

\section{Protease activity}

A medium that included $0.5 \%$ skim milk powder, $0.5 \%$ glucose and $2 \%$ agar ( $\mathrm{pH} 7.0)$ was used to assess the proteolytic activity of the isolates. The proteolytic microorganisms developing in this agar showed a brilliant zone (spot), while the medium remained turbid if the bacterial strain was devoid of this activity (Oztas Gulmus and Gormez 2020a).

\section{Results}

Study sites

The hot springs in Turkey (in the cities of Agri, Erzurum, Mardin, Sirnak and Van) are very close to volcanic fault systems (Mutlu and Güleç 1998). The altitude of the studied area is between 1125 and $1925 \mathrm{~m}$ above sea level. The source temperatures of the samples were measured as $38^{\circ} \mathrm{C}$ (Pasinler), $60{ }^{\circ} \mathrm{C}$
(Hista, Dargecit and Guclukonak) and $75{ }^{\circ} \mathrm{C}$ (Kopru, Davut and Hasanabdal). Most of the sources were found to be at "neutral $\mathrm{pH}$ ", except for the Hista, Köprü and Davut hot springs ( $\mathrm{pH} 8.5$ and 9.1).

Conventional analysis of the bacterial isolates

In the study, 83 bacterial isolates were isolated from Erzurum-Pasinler (26 isolates), Van-Hasanabdal (1 isolate), Siirt-Hista (6 isolates), Agri-Kopru (9 isolates), Agri-Davut (37 isolates), Mardin-Dargecit (2 isolates) and Sirnak-Guclukonak ( 2 isolates) at different temperatures $\left(40,55,65,70,75,85\right.$ and $\left.90{ }^{\circ} \mathrm{C}\right)$. The results of the morphological analyses showed that the bacterial isolates were Gram-positive and rodshaped, and they formed endospores, except for 9 isolates. The colonies of the isolates had cream, white and pink colors with rough, smooth or shiny surfaces and smooth or irregular edges. The optimum temperatures of the isolated bacteria were determined at 55 , 60 and $72{ }^{\circ} \mathrm{C}$. The isolates were examined for their tolerance to varying temperatures. The majority of the isolates $(97.5 \%)$ were accepted as obligate thermophiles with the optimum growth rates at temperatures in the range of $55-65{ }^{\circ} \mathrm{C}$. The remaining part of the isolates $(2.5 \%)$ was defined as thermotolerant with the optimum growth at $50-55^{\circ} \mathrm{C}$ (Panosyan et al. 2020).

The isolates were shown to have the optimum growth rate at $\mathrm{pH} 5.0-9.5$ and a $0-9 \% \mathrm{NaCl}$ concentration. The results of the physiological tests revealed that most isolates could grow within high temperature and $\mathrm{pH}$ ranges (Supplementary Table $\mathrm{S} 1$ ).

\section{S rRNA sequencing}

16S rRNA gene sequences were amplified with universal primers and visualized by gel electrophoresis. All isolates from the BLAST search were determined to contain $862-1419$ base pair nucleotides. The accession numbers were recorded in the NCBI database (Supplementary Table S1). All bacteria showing thermophilic properties (high temperatures ranging from 40 to $85^{\circ} \mathrm{C}$ ) were closely related to the genera of Bacillus, Weizmannia and Geobacillus. In total, 33 strains of B. subtilis (39.76\%), 15 strains of $G$. kaustophilus (18.07\%), 14 strains of B. licheniformis (16.87\%), 11 strains of W. coagulans (13.25\%) and 10 strains of Bacillus sp. (12.04\%) were identified 


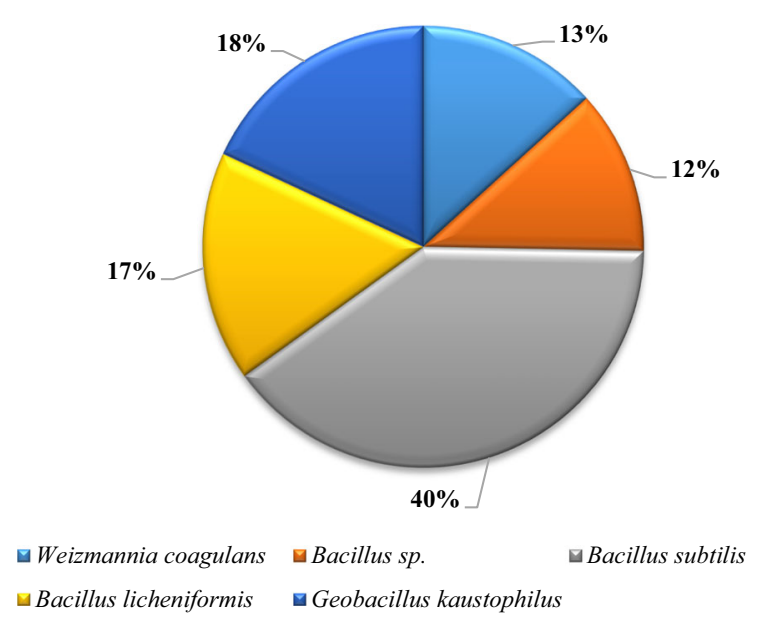

Fig. 2 Pie chart showing the distribution of bacteria resulting from sequencing in hot springs

(Fig. 2). According to the BLAST search, 10 isolates were registered as Bacillus sp. due to the affinity of BTX53-59, BTX72-73 and BTX79 to many different Bacilli with a high rate of sequence similarity. Based on the 16S rRNA gene sequence similarity analysis, 33 isolates demonstrated 95 to $99 \%$ sequence similarity to the species B. subtilis. Among the described species, a high sequence similarity of the isolates BTX42-47, BTX49, BTX50-52, BTX69-71, BTX77 and BTX80 to G. kaustophilus with a sequence homology rate of 97.59\% was determined. Among the described species, the closest relative of the isolates BTX1621, BTX29, BTX36-41 and BTX82 was B. licheniformis with a sequence homology rate of $98 \%$. According to the results of the sequencing analysis, the closest relative of the isolates BTX62-68, BTX7476 and BTX83 was $W$. coagulans with a sequence homology rate of 93.49-97.83\% (Table 1).

\section{Phylogenetic analysis}

The analysis of 89 nucleotide sequences ( 83 isolates, 1 outgroup, 5 type strains) was conducted using the neighbor-joining method and the MEGA7 software (Kumar et al. 2016). As shown in Fig. 3, the bacteria belonging to the genera Bacillus and Weizmannia were divided into distinct groups from the genus Geobacillus, to become a single group with type strains as expected. The results showed that there was no significant difference between the groups and the bacteria in terms of the locations or optimum temperatures of the isolates. The sequences of BTX1-BTX15, BTX30-BTX35, BTX48, BTX60 and BTX61 (0.038\%), BTX81 (0.039\%), BTX22-BTX28 $(0.041 \%)$ and BTX78 $(0.044 \%)$, differed from the $B$. subtilis Type Strain ATCC 6051, those of BTX62BTX68 (0.051\%), BTX74-BTX76 (0.059\%) and BTX83 $(0.051 \%)$ differed from the $W$. coagulans Type Strain ATCC7050, those of BTX53-BTX59 $(0.010 \%)$, BTX72 (0.014\%), BTX73 (0.008\%) and BTX79 $(0.012 \%)$ differed from the Bacillus sp. Type Strain ATCC 700,872, and those of BTX42-BTX47, BTX50-BTX52, BTX71 (0.010\%), BTX49, BTX69, BTX77, BTX80 (0.008\%) and BTX70 (0.009\%) differed from the G. kaustophilus Type Strain NBRC 102445. As seen in the similarity index data formed with the type strains of the closely related isolates, BTX16-BTX21, BTX29, BTX36-41 and BTX82 differed in the range of $0.040-0.043 \%$ from the $B$. licheniformis Type Strain ATCC 14580. In a polyphyly study of the genus Bacillus, it was reported that these strains (B. lichniformis and B. subtilis) in the subtilis clade are very close to each other (Patel and Gupta 2020). In this context, the results of our study were similar to those reported in other studies in the literature.

Determination of the enzyme production ability of the bacterial isolates

The abilities of the isolates to produce the amylase, cellulase, lipase and protease enzymes were investigated (Table 2 and Supplementary Fig. S1, S2 and S3 "A, B, C and D"). The qualitative analysis showed that $27(32.8 \%)$ of the isolates produced all hydrolase enzymes that were studied (amylase, cellulose, lipase and protease). In this study, 68 (82\%), 34 (41\%), 69 $(83 \%)$ and $73(88 \%)$ isolates were determined as producers of amylase, cellulose, lipase and protease, respectively. Except for four isolates (BTX9, BTX18, BTX27 and BTX55), all isolates were able to produce at least one of the studied enzymes (Fig. 4).

\section{Discussion}

The hot springs investigated in this study are in tectonically active parts of the Eastern and Southeastern Anatolia Regions of Turkey. Although similar studies have been conducted to isolate different 
Table 1 The characteristic features of bacterial isolates

\begin{tabular}{|c|c|c|c|c|c|c|c|c|c|}
\hline \multirow[t]{2}{*}{ Isolate code } & \multicolumn{4}{|c|}{ Physiological tests } & \multicolumn{5}{|c|}{ Morphological tests } \\
\hline & $\mathrm{pH}$ & $\begin{array}{l}\mathrm{NaCI} \\
(\%)\end{array}$ & $\begin{array}{l}\mathrm{T}_{\text {opt }}\left({ }^{\circ} \mathrm{C}\right) / \\
\text { temperature } \\
\left({ }^{\circ} \mathrm{C}\right)\end{array}$ & $\begin{array}{l}\text { Anaerobic } \\
\text { growth }\end{array}$ & Movement & Morphology & Chain & Endospore & $\begin{array}{l}\text { Gram } \\
\text { test }\end{array}$ \\
\hline 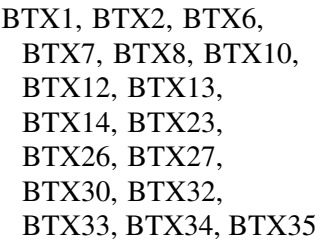 & $5-8.5$ & $\leq 9$ & $40-85 / 72$ & + & + & Bacil & + & + & + \\
\hline $\begin{array}{l}\text { ВТX3, ВTX4, ВТX5, } \\
\text { ВTX15, ВTX22, ВTX28 }\end{array}$ & $5-8.5$ & $\leq 9$ & $40-85 / 72$ & + & + & Bacil & - & + & + \\
\hline BTX25 & $5-8.5$ & $\leq 9$ & $40-85 / 72$ & - & + & Bacil & - & - & + \\
\hline $\begin{array}{l}\text { ВТХ9, ВТХ1, ВТХ24, } \\
\text { ВТX31 }\end{array}$ & $5-8.5$ & $\leq 9$ & $40-85 / 72$ & - & + & Bacil & - & + & + \\
\hline BTX16 & $5-8.5$ & $\leq 5$ & $40-85 / 72$ & + & + & Coco Bacil & - & + & + \\
\hline ВТX17, ВТХ36 & $5-8.5$ & $\leq 5$ & $40-85 / 72$ & + & + & Bacil & - & + & + \\
\hline BTX18 & $5-8.5$ & $\leq 5$ & $40-85 / 72$ & + & + & Bacil & - & - & + \\
\hline BTX19 & $5-8.5$ & $\leq 5$ & $40-85 / 72$ & - & + & Bacil & + & + & + \\
\hline ВТХ20, ВТХ21 & $5-8.5$ & $\leq 5$ & $40-85 / 72$ & + & + & Bacil & + & + & + \\
\hline ВТX29 & $5-7.5$ & $\leq 5$ & $40-85 / 72$ & + & + & Bacil & + & + & + \\
\hline ВTX37 & $5-7.5$ & $<5$ & $40-75 / 60$ & - & + & Bacil & - & + & + \\
\hline ВTX38 & $5-7.5$ & $<5$ & $40-75 / 60$ & + & + & Bacil & - & + & + \\
\hline ВTX39 & $5-7.5$ & $<5$ & $40-75 / 60$ & + & + & Bacil & + & + & + \\
\hline ВТX40, ВТХ41 & $5-7.5$ & $<5$ & $40-75 / 60$ & + & + & Bacil & + & + & + \\
\hline ВТХ42, ВТХ50 & $5-7.5$ & $<7$ & $40-75 / 60$ & + & + & Bacil & - & + & + \\
\hline BTX43 & $5-7.5$ & $<7$ & $40-75 / 60$ & - & + & Bacil & + & + & + \\
\hline BTX44 & $5-7.5$ & $<7$ & $40-75 / 60$ & - & + & Bacil & - & + & + \\
\hline ВТХ45, ВТХ46, ВТХ47 & $5-7.5$ & $<7$ & $40-75 / 60$ & + & + & Bacil & + & + & + \\
\hline ВТХ48, ВТХ78 & $5-7.5$ & $\leq 9$ & $40-75 / 60$ & - & + & Bacil & - & - & + \\
\hline BTX49 & $5-7.5$ & $<7$ & $40-75 / 60$ & + & + & Bacil & - & - & + \\
\hline BTX51 & $5-7.5$ & $<7$ & $40-85 / 72$ & + & + & Bacil & - & - & + \\
\hline BTX52 & $5-7.5$ & $<7$ & $40-85 / 72$ & - & + & Bacil & - & + & + \\
\hline ВTX53 & $6-9.5$ & $<7$ & $40-85 / 72$ & + & + & Bacil & + & + & + \\
\hline BTX54 & $6-9.5$ & $<7$ & $40-85 / 72$ & + & + & Bacil & + & + & + \\
\hline BTX55 & $6-9.5$ & $<7$ & $40-85 / 72$ & - & + & Bacil & - & + & + \\
\hline ВTX56 & $6-7.5$ & $<7$ & $40-70 / 55$ & + & + & Bacil & + & + & + \\
\hline BTX57 & $6-7.5$ & $<7$ & $40-70 / 55$ & + & + & Bacil & - & + & + \\
\hline BTX58 & $5-7.5$ & $<7$ & $40-75 / 60$ & - & + & Bacil & - & - & + \\
\hline ВTX59 & $5-7.5$ & $<7$ & $40-75 / 60$ & + & + & Bacil & + & + & + \\
\hline ВТX60 & $6-9.5$ & $\leq 9$ & $40-85 / 72$ & + & + & Bacil & + & + & + \\
\hline BTX61 & $6-9.5$ & $\leq 9$ & $40-85 / 72$ & - & + & Bacil & - & - & + \\
\hline ВТХ62, ВТХ63 & $5-8.5$ & $\leq 6$ & $40-85 / 72$ & + & + & Bacil & + & + & + \\
\hline ВТX64 & $5-8.5$ & $\leq 6$ & $40-85 / 72$ & + & + & Bacil & - & + & + \\
\hline $\begin{array}{l}\text { ВТХ65, ВТХ66, ВТХ67, } \\
\text { ВТХ68 }\end{array}$ & $5-7.5$ & $\leq 6$ & $40-85 / 72$ & + & + & Bacil & + & + & + \\
\hline ВТХ69, ВТХ71 & $5.5-7.5$ & $<7$ & $40-75 / 60$ & + & + & Bacil & - & + & + \\
\hline
\end{tabular}


Table 1 continued

\begin{tabular}{|c|c|c|c|c|c|c|c|c|c|}
\hline \multirow[t]{2}{*}{ Isolate code } & \multicolumn{4}{|c|}{ Physiological tests } & \multicolumn{5}{|c|}{ Morphological tests } \\
\hline & $\mathrm{pH}$ & $\begin{array}{l}\mathrm{NaCI} \\
(\%)\end{array}$ & $\begin{array}{l}\mathrm{T}_{\text {opt }}\left({ }^{\circ} \mathrm{C}\right) / \\
\text { temperature } \\
\left({ }^{\circ} \mathrm{C}\right)\end{array}$ & $\begin{array}{l}\text { Anaerobic } \\
\text { growth }\end{array}$ & Movement & Morphology & Chain & Endospore & $\begin{array}{l}\text { Gram } \\
\text { test }\end{array}$ \\
\hline ВТX70, ВТХ72, ВТХ73 & $5.5-7.5$ & $<7$ & $40-75 / 60$ & + & + & Bacil & + & + & + \\
\hline BTX74 & $5.5-7.5$ & $<6$ & $40-75 / 60$ & + & + & Bacil & + & + & + \\
\hline ВТX75, ВТX76 & $5.5-7.5$ & $<6$ & $40-75 / 60$ & + & + & Bacil & - & + & + \\
\hline BTX77 & $6-7.5$ & $<7$ & $40-75 / 60$ & + & + & Bacil & - & - & + \\
\hline ВТX79 & $5-8$ & $<7$ & $40-85 / 72$ & + & + & Bacil & + & + & + \\
\hline BTX80 & 6.7 .5 & $<6$ & $40-85 / 72$ & + & + & Bacil & + & + & + \\
\hline BTX81 & $5-7.5$ & $\leq 9$ & $40-85 / 72$ & + & + & Bacil & + & + & + \\
\hline ВТX82 & $5-7.5$ & $<7$ & $40-85 / 72$ & + & + & Bacil & + & + & + \\
\hline ВТX83 & $5-7.5$ & $<6$ & $40-85 / 72$ & + & + & Bacil & + & + & + \\
\hline
\end{tabular}

$T_{\text {opt }}$ Optimum temperature

thermophilic bacteria species in hot springs in these regions, different species have been detected in hot springs such as Hasanabdal, Kopru, Pasinler and Hista. According to the results of this study, B. subtilis (33), G. kaustophilus (15), B. licheniformis (14 isolates), W. coagulans (11) and Bacillus sp. (10) were identified as the most common Bacilli in the area. Amongst the isolated bacteria, Bacillus was the most dominant genus isolated from the hot springs examined in this study. In general, temperature is a very important parameter in controlling the richness and diversity of microorganisms in hot springs (Wang et al. 2013). Several studies on microbial diversity in hot springs have also reported on the abundance and diversity of Bacillus species (Abdollahi et al. 2021; Baltaci et al. 2017; Ifandi and Alwi 2018; Margaryan et al. 2018; Oztas Gulmus and Gormez 2020b; Panosyan et al. 2020). Although the locations of the Davut and Kopru hot springs are very close to each other, the isolated bacteria were quite different. B. subtilis and $B$. licheniformis were isolated from Davut, and $W$. coagulans was also isolated from Kopru. The locations of the other hot springs differ completely from each other. W. coagulans and Bacillus sp. were isolated from Hista for the first time. W. coagulans was isolated from Diyadin and Hasanabdal for the first time. Geobacillus sp. and B. licheniformis were reported from Hasanabdal in similar studies (Poddar and Das 2018). Besides, the strains identified within this study (B. subtilis, G. kaustophilus, B. licheniformis, W. coagulans and Bacillus sp.) exhibited similar morphological, characteristic, physiological and biochemical properties in comparison to those reported in the literature (Baltaci et al. 2017; Oztas Gulmus and Gormez 2020a). All isolated strains ( $W$. coagulans, Bacillus sp., B. subtilis, Geobacillus sp. and $B$. licheniformis) exhibited the ability to grow normally at high temperatures and $\mathrm{pH}$ values, which was not typical. The strains could grow at temperatures ranging from 40 to $85{ }^{\circ} \mathrm{C}, \mathrm{NaCl}$ levels up to $9 \%$ $(\mathrm{w} / \mathrm{v})$ and $\mathrm{pH}$ ranges from 4 to 9 . Only the strains belonging to the $B$. licheniformis isolates were able to grow on $\mathrm{NaCl}$ levels below $5 \%$ at $40-75{ }^{\circ} \mathrm{C}$ (optimum at $60{ }^{\circ} \mathrm{C}$ ) and $\mathrm{pH} 4$ to 9 (optimum at $\mathrm{pH} 7$ ).

Microbial enzymes, especially enzymes derived from extremophile organisms, are widely used in different fields today. Thermophilic organisms are also microorganisms that adapt to extreme conditions, and so, they can create a variety of products that can be used even in unfavorable conditions. Many enzymes from thermophilic organisms such as amylase, catalase, cellulase, lactase, lipase, pectinase, pullulanase, protease, sucrase and xylanase are purified and produced commercially. These enzymes are widely used in many fields such as the textile, food, detergent, industry, beverage and health sectors (Oztas Gulmus and Gormez 2020b). The results obtained in this study are very important for further taxonomic studies and for understanding the ecological and environmental effects of microorganisms. Positive findings related to 


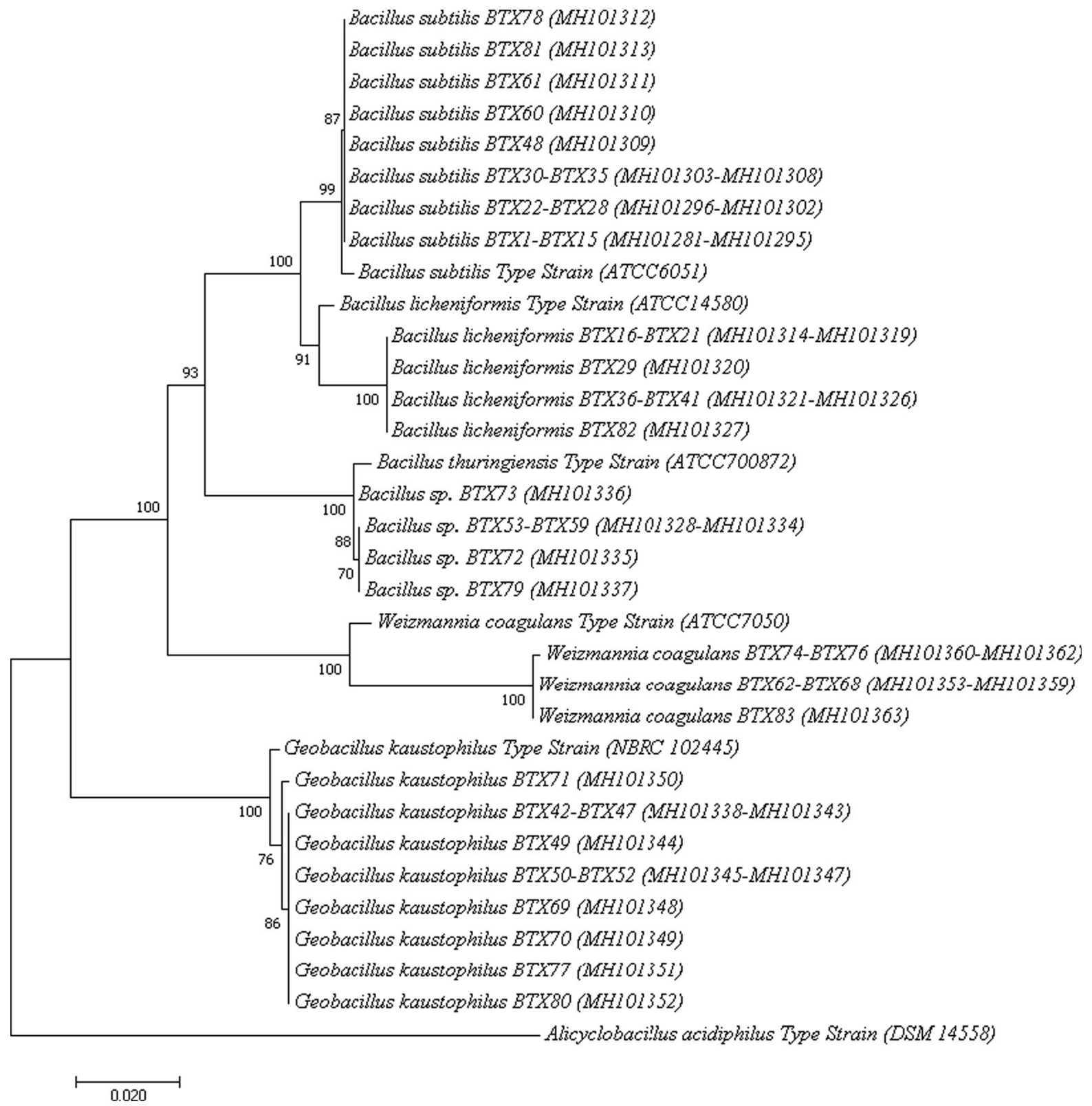

Fig. 3 The evolutionary relationship was inferred using the Neighbor-Joining method (Saitou and Nei 1987). The optimal tree with the sum of branch length $=0.34292109$ is shown. The percentages of the replicate trees in which the associated taxa clustered together in the bootstrap test (1000 replicates) are shown next to the branches (Felsenstein 1992). The tree is drawn to scale, with branch lengths in the same units as those of the evolutionary distances used to infer the phylogenetic tree. The

microorganisms and their hydrolytic activity performances are in a remarkable position in terms of biotechnological applications. In this study, the ability producing of thermostable enzymes (amylases, evolutionary distances were computed using the p-distance method (Nei and Kumar 2000) and are in the units of the number of base differences per site. The analysis involved 33 nucleotide sequences. All positions containing gaps and missing data were eliminated. There were 754 positions in the final dataset in total. The evolutionary analyses were conducted in MEGA7 (Kumar et al. 2016)

cellulases, lipases and proteases) of the isolates was also determined. A number of isolates were identified throughout the study that demonstrated the activity of at least one hydrolytic enzyme. The qualitative study 


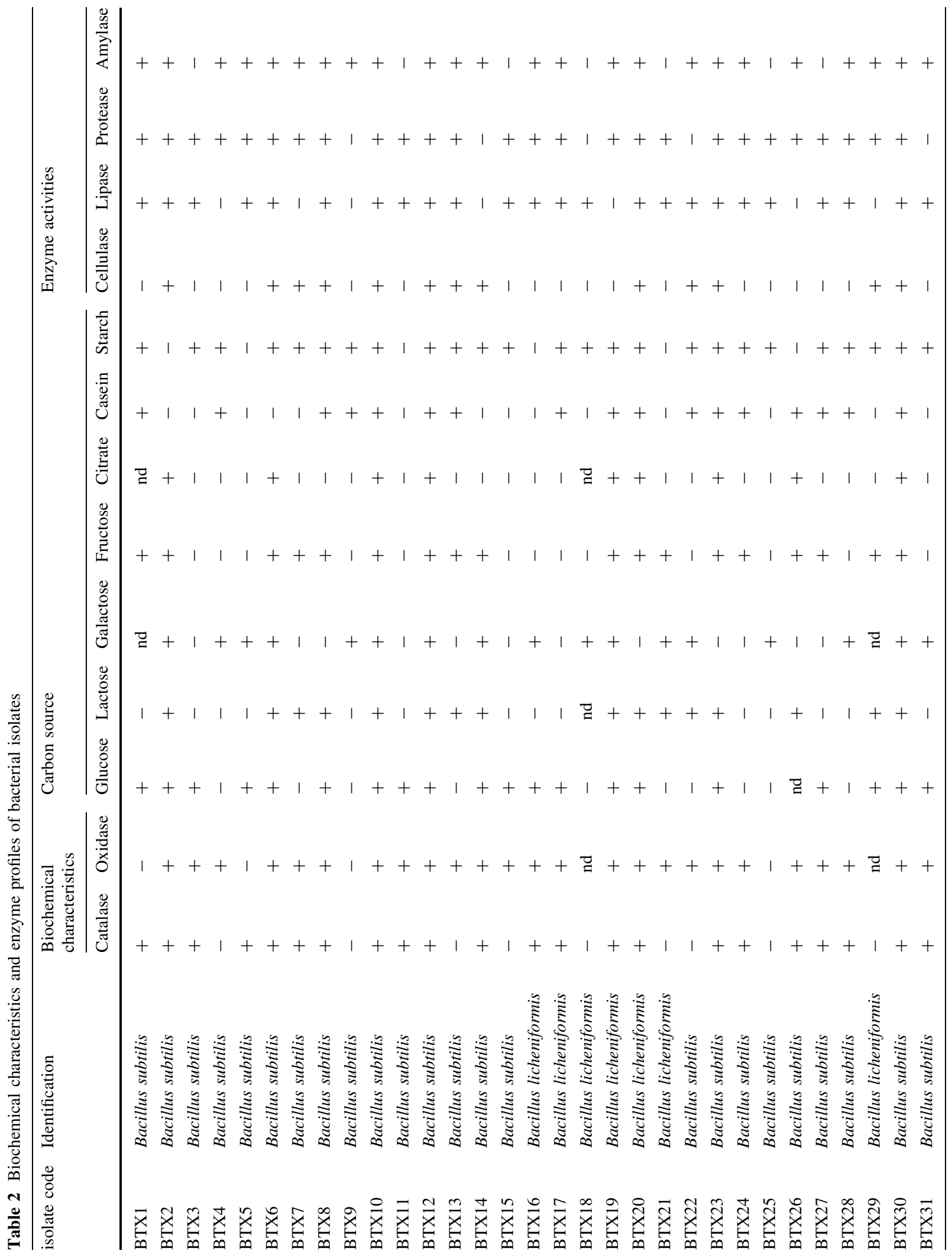




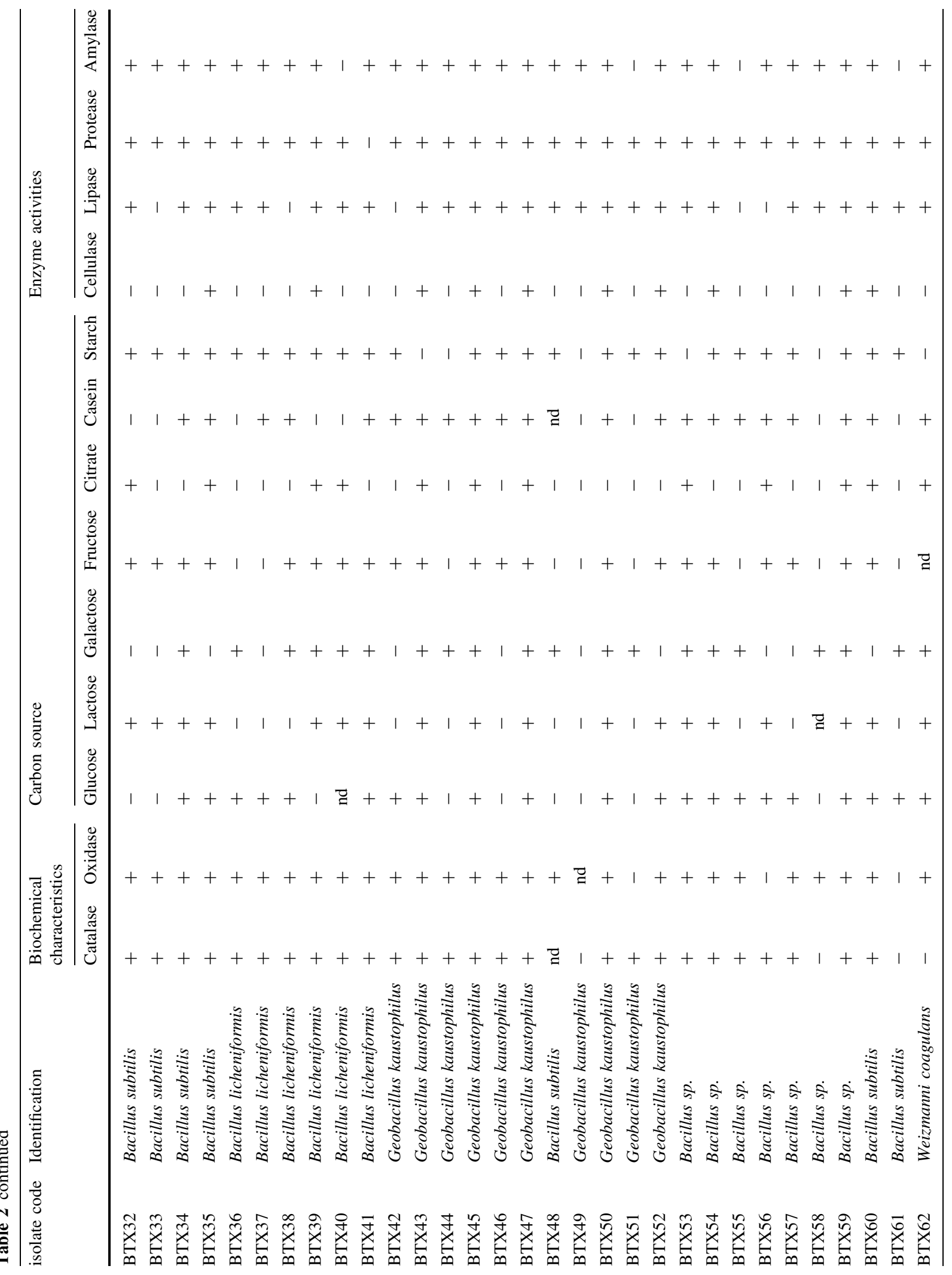




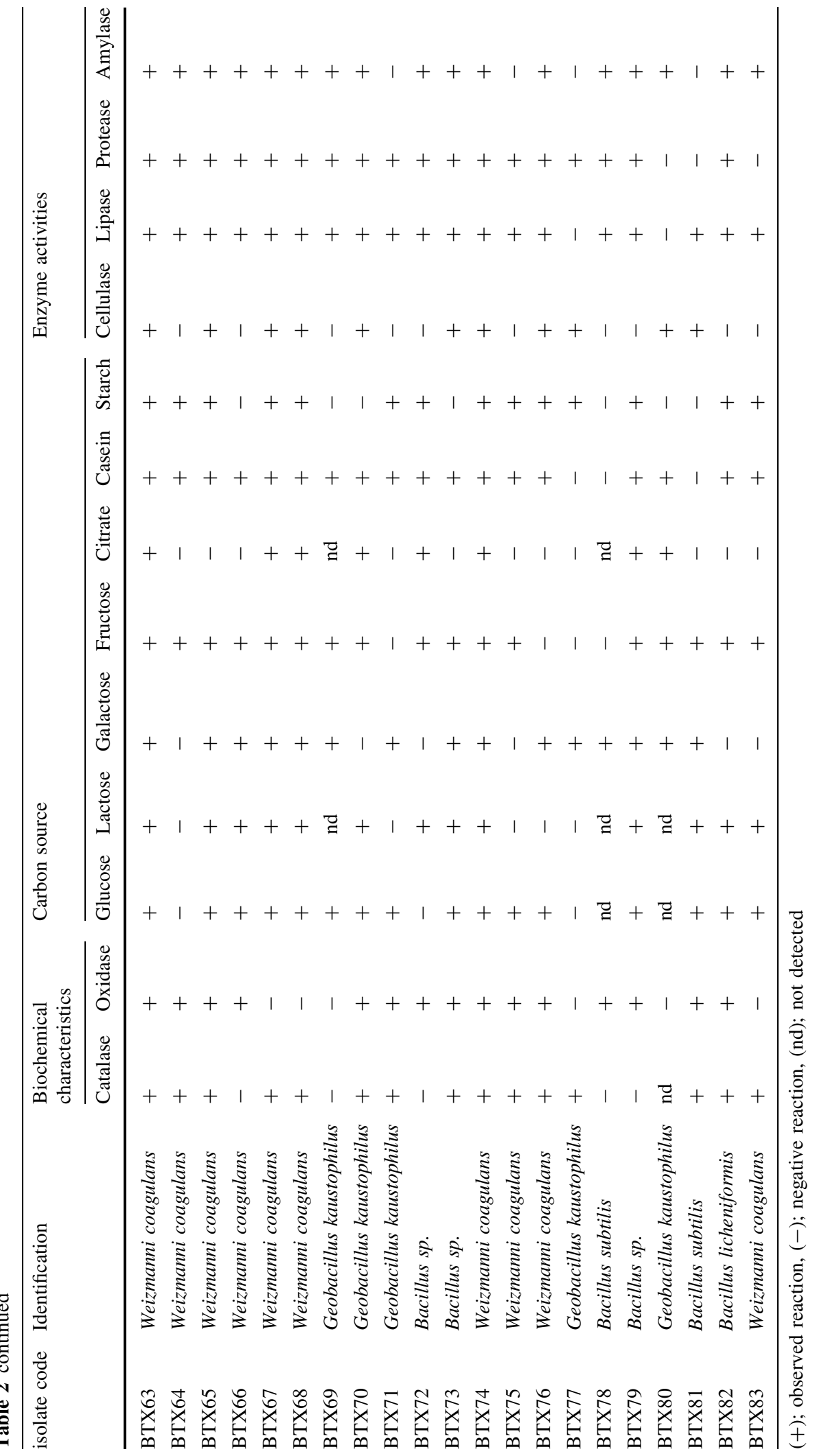



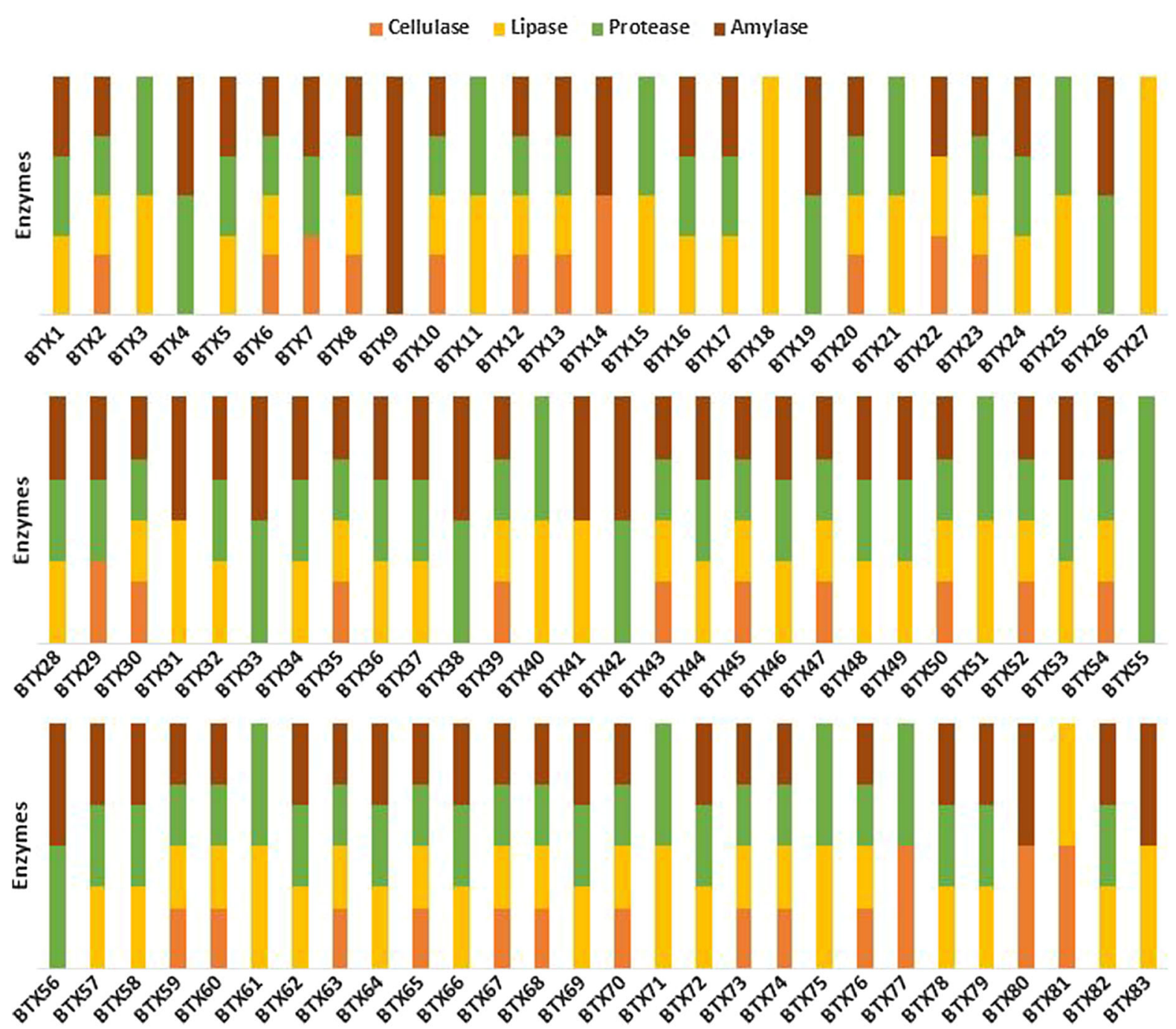

Fig. 4 According to the qualitative analysis results, it was determined that $27(32.8 \%)$ isolates could produce amylase, protease, cellulase and lipase. In the study, 68 (82\%), 73 (88\%),

results revealed that $27(32.8 \%)$ bacterial isolates had amylase, cellulase, lipase and protease production capacity. These bacterial isolates were B. subtilis (10 isolates), G. kaustophilus (6 isolates), W. coagulans (6 isolates), Bacillus sp. (3 isolates) and B. licheniformis (2 isolates). Similarly, there are many studies on the enzyme activities of Bacillus, Geobacillus, Weizmannia and Anoxybacillus species in the literature (Baltaci et al. 2017; Mohammad et al. 2017; Oztas Gulmus and Gormez 2020a; Yanmis et al. 2015). According to Baltaci et al., Bacillus pumilus and B. licheniformis showed amylase, cellulose, lipase and protease activities (Baltaci et al. 2017). Amylase, cellulase, lipase
$34(41 \%)$ and $69(83 \%)$ isolates were determined as producers of amylase, protease, cellulase and lipase, respectively

and protease are in the class of hydrolytic enzymes that are very important for industrial applications. Among these, amylases are used in industrial processes such as starch hydrolysis, production of fruit juices and fruit syrups, textile, beer, ethanol fermentation, starch processing, detergents, bread production and wastewater treatment (Aiyer 2005; Lahiri et al. 2021). Lipases are frequently used in the cleaning (detergent), nutrition (food), health (pharmaceutical) and agriculture (chemicals) industries. Having a very broad place in the international market $(60 \%)$, proteases have a wide range of uses in various sectors such as nutrition (food), cleaning (detergent), leather (textile), 
cosmetics (perfumery) and medicine (pharmaceuticals) (Gupta et al. 2002; Laxman et al. 2005). Hydrolytic enzymes are popular and frequently used in the industry (Oztas Gulmus and Gormez 2020b). Moreover, the cellulase enzyme has a wide range of applications in biotechnological and industrial fields. Some of the important applications it has are in the food, feed, beer, wine, textile, detergent, paper and agricultural industries. Despite the commercial importance of this enzyme, its high production cost limits its use in the industry for the transformation of cellulose. Therefore, research on new and different sources of microbial cellulase for more stable and active enzymes has increased. Bacillus species, which can be isolated from many environments, as well as hot water sources, are of great importance in terms of enzyme production. They are also some of the most effective proteolytic and carbohydrate sources. They meet the enzyme needs in many areas such as the production of starch, bread, fruit juice, paper bleaching and brewing (Bhati and Sharma 2021; Kurt and Cekmecelioglu 2021; Singh et al. 2021). For this reason, many enzymes synthesized by Bacillus species are used in many areas in the industry (Oztas Gulmus and Gormez 2020b). Bacteria isolated in this study may be preferred in future studies because they can grow at high temperatures, varying salinity $(\mathrm{NaCl})$ and $\mathrm{pH}$ ranges, and they produce stable enzymes that can work in extreme conditions.

\section{Conclusions}

In this study, bacterial isolates were identified with 16S rRNA gene sequencing from seven hot springs in the Eastern and Southeastern Anatolia Regions of Turkey. According to the $16 \mathrm{~S}$ rRNA sequencing results, most of the bacterial isolates were observed to belong to the genera Bacillus (68.67\%), Weizmannia $(13.25 \%)$ and Geobacillus (18.07\%). These results showed that Bacillus was the most dominant genus among all isolates in the seven hot springs from where the samples were collected.

Although the bacteria isolated from the different hot springs were similar on the genus level, they were quite diverse in terms of their environmental attributes, encompassing a temperature range from 40 to $85^{\circ} \mathrm{C}$, a pH range from 4 to 9 , and a salinity range from 0 to $9 \%$. Because of these important properties, wide $\mathrm{pH}$ and temperature ranges, these enzymes can be preferred in industrial applications. In this context, this is a preliminary study showing the diversity of bacteria that produce crucial thermophilic enzymes in industrial and biotechnological terms.

Acknowledgements The identification of bacterial species in the study was presented in 2017 as an abstract for an international conference.

Authors' contributions OU, Conceptualization, Methodology, Validation, Investigation, Resources, Formal analysis, Writing-Original Draft, Writing-Review \& Editing; AG, Methodology, Investigation, Resources, Supervision. CO, Conceptualization, Methodology, Investigation, Resources. All authors read and approved the final manuscript.

Funding This study was supported by the Scientific Research Projects Coordination Unit of Kafkas University (2016-FM-24).

Data availability The datasets generated and/or analyzed during the current study are available from supplementary information files and the corresponding author on reasonable request.

\section{Declarations}

Conflict of interest The authors declare that they have no conflict of interest.

Ethical approval This article does not contain any studies with human participants or animals performed by any of the authors.

\section{References}

Aanniz T, Ouadghiri M, Melloul M, Swings J, Elfahime E, Ibijbijen J, Ismaili M, Amar M (2015) Thermophilic bacteria in Moroccan hot springs, salt marshes and desert soils. Braz J Microbiol 46(2):443-453

Abdollahi P, Ghane M, Babaeekhou L (2021) Isolation and characterization of thermophilic bacteria from gavmesh goli hot spring in sabalan geothermal field, Iran: thermomonas hydrothermalis and Bacillus altitudinis 1solates as a potential source of thermostable protease. Geomicrobiol J 38(1):87-95

Abootalebi SN, Saeed A, Gholami A, Mohkam M, Kazemi A, Nezafat N, Mousavi SM, Hashemi SA, Shorafa E (2020) Screening, characterization and production of thermostable alpha-amylase produced by a novel thermophilic Bacillus megaterium isolated from pediatric intensive care unit. J Environ Treat Tech 8(3):952-960

Acer Ö, Prınççiğlu H, Bekler FM, Gül-Güven R (2015) Anoxybacillus sp. AH1, an $\alpha$-amylase-producing 
thermophilic bacterium isolated from Dargeçit hot spring. Biologia 70(7):853-862

Adiguzel A, Inan K, Sahin F, Arasoglu T, Gulluce M, Belduz AO, Baris O (2011) Molecular diversity of thermophilic bacteria isolated from Pasinler hot spring (Erzurum, Turkey). Turk J Biol 35(3):267-274

Aiyer P (2005) Amylases and their applications. Afr J Biotechnol 4:1525-1529

Akita H, Kimura Z-I, Matsushika A (2017) Complete genome sequence of Ureibacillus thermosphaericus A1, a thermophilic bacillus solated from compost. Genome Announc 5(38):e00910-e917

Al-Johani NB, Al-Seeni MN, Ahmed YM (2016) Optımızation of alkaline $\alpha$-amylase production by thermophilic Bacillus subtilis. Afr J Trad Complement Alternat Med: AJTCAM 14(1):288-301

Baltaci MO, Genc B, Arslan S, Adiguzel G, Adiguzel A (2017) Isolation and characterization of thermophilic bacteria from geothermal areas in turkey and preliminary research on biotechnologically 1mportant enzyme production. Geomicrobiol J 34(1):53-62

Bernard K, Burdz T, Wiebe D, Balcewich BM, Zimmerman T, Lagacé-Wiens P, Hoang LM, Bernier A-MJA (2017) Characterization of isolates of Eisenbergiella tayi, a strictly anaerobic Gram-stain variable bacillus recovered from human clinical materials in Canada. Anaerobe 44:128-132

Bernardo SPC, Rosana ARR, de Souza AN, Chiorean S, Martins MLL, Vederas JC (2020) Draft genome sequence of the thermophilic bacterium Bacillus licheniformis SMIA-2, an Antimicrobial- and thermostable enzyme-producing 1solate from Brazilian soil. Microbiol Resource Announc 9(17):e00106-e120

Bhati N, Sharma AK (2021) Cost-effective cellulase production, improvement strategies, and future challenges. J Food Process Eng 44(2):e13623

Dang TCH, Nguyen DT, Thai H, Nguyen TC, Tran TTH, Le VH, Van Huynh N, Tran XB, Pham TPT, Nguyen TG, Nguyen QT (2018) Plastic degradation by thermophilic Bacillus sp. BCBT21 isolated from composting agricultural residual in Vietnam. Adv Nat Sc Nanosci Nanotechnol 9(1):015014

Derya Y, Ahmet A (2014) Molecular typing of thermophilic bacilli isolated from different hot springs of Turkey. Res J Biotechnol 9(10):83-88

Eriksen NT (2008) Production of phycocyanin — a pigment with applications in biology, biotechnology, foods and medicine. Appl Microbiol Biotechnol 80(1):1-14

Ertuğrul S, Dönmez G, Takaç S (2007) Isolation of lipase producing Bacillus sp. from olive mill wastewater and improving its enzyme activity. J Hazard Mater 149(3):720-724

Falcicchio P, Levisson M, Kengen SW, Koutsopoulos S, van der Oost J (2021) (Hyper) thermophilic enzymes: production and purification. In: Labrou NE (ed) Protein downstream processing. Springer, Berlin, pp 469-478

Felsenstein J (1992) Phylogenies from restriction sites: a maximum-likelihood approach. Evolution 46(1):159-173

Gormez A, Sahin F, Gulluce M, Aslan I (2013) Identification and characterization of Pseudomonas syringae isolated from apricot trees in the erzurum province of Turkey and evaluation of cultivar reaction. J Plant Pathol 95:525-532

Gupta R, Beg QK, Khan S, Chauhan B (2002) An overview on fermentation, downstream processing and properties of microbial alkaline proteases. Appl Microbiol Biotechnol 60(4):381-395

Guven K, Matpan Bekler F, Gul Guven R (2018) Thermophilic and halophilic microorganisms isolated from extreme environments of Turkey, with potential biotechnological applications. In: Egamberdieva D, Birkeland N-K, Panosyan H, Li W-J (eds) Extremophiles in Eurasian ecosystems: ecology, diversity, and applications. Springer, Singapore, pp 219-264

Hogendoorn C, Picone N, van Hout F, Vijverberg S, Poghosyan L, van Alen TA, Frank J, Pol A, Gagliano AL, Jetten MSM (2021) Draft genome of a novel methanotrophic Methylobacter sp. from the volcanic soils of Pantelleria Island. Antonie Van Leeuwenhoek 114(3):313-324

Ifandi S, Alwi M (2018) Isolation of thermophilic bacteria from Bora hot springs in Central Sulawesi. J Biol Biol Educ 10(2):291-297

Jacobus AP, Gross J (2015) Optimal cloning of PCR fragments by homologous recombination in Escherichia coli. PLoS ONE 10(3):e0119221

Khan M, Sathya TA (2018) Extremozymes from metagenome: potential applications in food processing. Crit Rev Food Sci Nutr 58(12):2017-2025

Kumar S, Stecher G, Tamura K (2016) MEGA7: molecular evolutionary genetics analysis version 7.0 for bigger datasets. Mol Biol Evol 33(7):1870-1874

Kurt AS, Cekmecelioglu D (2021) Bacterial cellulase production using grape pomace hydrolysate by shake-flask submerged fermentation. In: Kaltschmitt M, Hofbauer H (eds) Biomass conversion and biorefinery. Springer, Berlin, pp 1-8

Ladeira SA, Cruz E, Delatorre AB, Barbosa JB, Martins MLL (2015) Cellulase production by thermophilic Bacillus sp. SMIA-2 and its detergent compatibility. Electron J Biotechnol 18(2):110-115

Lahiri D, Nag M, Sarkar T, Dutta B, Ray RR (2021) Antibiofilm Activity of $\alpha$-Amylase from Bacillus subtilis and Prediction of the Optimized Conditions for Biofilm Removal by Response Surface Methodology (RSM) and Artificial Neural Network (ANN). Appl Biochem Biotechnol 193(6):1853-1872

Laxman RS, Sonawane AP, More SV, Rao BS, Rele MV, Jogdand VV, Deshpande VV, Rao MB (2005) Optimization and scale up of production of alkaline protease from Conidiobolus coronatus. Process Biochem 40(9):3152-3158

Lee HS, Kwon KK, Kang SG, Cha S-S, Kim S-J, Lee J-H (2010) Approaches for novel enzyme discovery from marine environments. Curr Opin Biotechnol 21(3):353-357

Li X, Zhao X, Tian D, Zhu Y, Yao T (1999) A new method for PCR products cloning-T-A clone technique. Sheng Wu Hua Xue Yu Sheng Wu Wu Li Jin Zhan 26(2):187-189

Luo Z, Miao J, Li G, Du Y, Yu X (2017) A Recombinant Highly Thermostable $\beta$-Mannanase (ReTMan26) from Thermophilic Bacillus subtilis (TBS2) Expressed in Pichia pastoris and Its $\mathrm{pH}$ and Temperature Stability. Appl Biochem Biotechnol 182(4):1259-1275 
Margaryan A, Shahinyan G, Hovhannisyan P, Panosyan H, Birkeland N-K, Trchounian A (2018) Geobacillus and Anoxybacillus spp. from terrestrial geothermal springs worldwide: diversity and biotechnological applications. In: Egamberdieva D, Birkeland N-K, Panosyan H, Li W-J (eds) Extremophiles in Eurasian ecosystems: ecology, diversity, and applications. Springer, Singapore, pp 119-166

Mehta R, Singhal P, Singh H, Damle D, Sharma AK (2016) Insight into thermophiles and their wide-spectrum applications. 3 Biotech 6(1):81-81

Mohammad BT, Al Daghistani HI, Jaouani A, Abdel-Latif S, Kennes C (2017) Isolation and characterization of thermophilic bacteria from jordanian hot springs: Bacillus licheniformis and Thermomonas hydrothermalis isolates as potential producers of thermostable enzymes. Int $\mathbf{J}$ Microbiol 2017:6943952

Msarah MJ, Ibrahim I, Hamid AA, Aqma WS (2020) Optimisation and production of alpha amylase from thermophilic Bacillus spp. and its application in food waste biodegradation. Heliyon 6(6):e04183-e4191

Mutlu H, Güleç N (1998) Hydrogeochemical outline of thermal waters and geothermometry applications in Anatolia (Turkey). J Volcanol Geoth Res 85(1):495-515

Nei M, Kumar S (2000) Molecular evolution and phylogenetics. Oxford University Press, Oxford

Oztas Gulmus E, Gormez A (2020a) Characterization and biotechnological application of protease from thermophilic thermomonas haemolytica. Arch Microbiol 202(1):153-159

Oztas Gulmus E, Gormez A (2020b) Identification and characterization of novel thermophilic bacteria from hot springs, Erzurum, Turkey. Curr Microbiol 77(6):979-987

Panosyan H, Margaryan A, Birkeland N-K (2020) Geothermal springs in Armenia and Nagorno-Karabakh: potential sources of hydrolase-producing thermophilic bacilli. Extremophiles 24(4):519-536

Patel S, Gupta RS (2020) A phylogenomic and comparative genomic framework for resolving the polyphyly of the genus Bacillus: Proposal for six new genera of Bacillus species, Peribacillus gen. nov., Cytobacillus gen. nov., Mesobacillus gen. nov., Neobacillus gen. nov., Metabacillus gen. nov. and Alkalihalobacillus gen. nov. Int J Syst Evol Microbiol 70(1):406-438

Poddar A, Das SK (2018) Microbiological studies of hot springs in India: a review. Arch Microbiol 200(1):1-18

Poli A, Guven K, Romano I, Pirinccioglu H, Guven RG, Euzeby JP, Matpan F, Acer O, Orlando P, Nicolaus B (2012) Geobacillus subterraneus subsp. aromaticivorans subsp. nov., a novel thermophilic and alkaliphilic bacterium isolated from a hot spring in Sirnak, Turkey. J Gen Appl Microbiol 58(6):437-446

Prescott H (2002) Laboratory exercises in microbiology, 5th edn. Wiley, Hoboken

Prescott LM, Harley JP (2002) Laboratory exercises in microbiology, 5th edn. Wiley, Hoboken

Saeed AM, Sayed HAE, El-Shatoury EH (2020) Optimizing the reduction of molybdate by two novel thermophilic bacilli isolated from Sinai, Egypt. Curr Microbiol 77(5):786-794

Safitri R, Kusumawardhani DP, Annisa A, Partasasmita R, Asharina S, Maskoen AM (2020) Characterization and identification of three thermophilic Bacillus strain isolated from Domas Crater, Mt. Tangkuban Perahu. Indonesia Biodiver J Biol Divers. https://doi.org/10.13057/biodiv/ d210805

Saitou N, Nei M (1987) The neighbor-joining method: a new method for reconstructing phylogenetic trees. Mol Biol Evol 4(4):406-425

Saleh F, Hussain A, Younis T, Ali S, Rashid M, Ali A, Mustafa G, Jabeen F, Al-Surhanee AA, Alnoman MM, Qamer S (2020) Comparative growth potential of thermophilic amylolytic Bacillus sp. on unconventional media food wastes and its industrial application. Saudi J Biol Sci 27(12):3499-3504

Salem RB, Abbassi MS, Cayol J-L, Bourouis A, Mahrouki S, Fardeau M-L, Belhadj O (2020) Thermophilic Bacillus licheniformis RBS 5 isolated from hot Tunisian spring coproducing alkaline and thermostable $\alpha$-amylase and protease enzymes. J Microbiol Biotechnol Food Sci 5(6):557-562

Sambrook J (1987) Commonly used techniques in molecular cloning. Mol Clon 3:E1-E39

Savas S, Adiguzel A, Inan K, Ozkan H, Gulluce M, Sahin F (2009) Molecular characterization of thermophilic bacteria isolated from Van City Ercis Town Hasanabdal hot spring. Roman Biotechnol Lett 14(3):4445-4454

Shen P, Niu D, Liu X, Tian K, Kugenthiren P, Singh S, Wang Z (2021) Overexpression of thermophilic $\alpha$-amylase in Bacillus Licheniformis using a high efficiency chromosomal integration and amplification strategy. Microbial Cell Factories

Short JM (1998) Directed evolution of thermophilic enzymes

Singh A, Bajar S, Devi A, Pant D (2021) An overview on the recent developments in fungal cellulase production and their industrial applications. Bioresource Technol Rep 14:100652

Tango MSA, Islam MR (2002) Potential of extremophiles for biotechnological and petroleum applications. Energy Sources 24(6):543-559

Thakur A, Sharma K, Mutreja R, Goyal A (2021) Thermostable Enzymes from Clostridium thermocellum. In: Thatoi H, Mohapatra S, Das SK (eds) Bioprospecting of enzymes in industry, healthcare and sustainable. Springer, Berlin, pp 251-267

Tsotetsi L, Prenaven R, Modise S, Monapathi M (2020) Isolation and identification of xylanase producing thermophilic bacteria from compost piles and optimization of xylanase production. J Biotech Res 11:122-132

Verma JP, Jaiswal DK, Krishna R, Prakash S, Yadav J, Singh V (2018) Characterization and screening of thermophilic bacillus strains for developing plant growth promoting consortium from hot spring of Leh and Ladakh Region of India. Front Microbiol 9:1293

Wang L, Tang Y, Wang S, Liu RL, Liu MZ, Zhang Y, Liang FL, Feng L (2006) Isolation and characterization of a novel thermophilic Bacillus strain degrading long-chain n-alkanes. Extremophiles 10(4):347-356

Wang S, Hou W, Dong H, Jiang H, Huang L, Wu G, Zhang C, Song Z, Zhang Y, Ren H (2013) Control of temperature on microbial community structure in hot springs of the Tibetan Plateau. PLoS ONE 8(5):e62901 
Yadav P, Korpole S, Prasad GS, Sahni G, Maharjan J, Sreerama L, Bhattarai T (2018) Morphological, enzymatic screening, and phylogenetic analysis of thermophilic bacilli isolated from five hot springs of Myagdi, Nepal. J Appl Biol Biotechnol 6(3):1-8

Yanmis D, Baltaci MO, Gulluce M, Adiguzel A (2015) Identification of thermophilic strains from geothermal areas in Turkey by using conventional and molecular techniques. Res J Biotechnol 10(1):39-45

Yilmaz B, Baltaci MO, Sisecioglu M, Adiguzel A (2016) Thermotolerant alkaline protease enzyme from Bacillus licheniformis A10: purification, characterization, effects of surfactants and organic solvents. J Enzyme Inhibition Med Chem 31(6): 1241-1247

Zakzeski J, Bruijnincx PC, Jongerius AL, Weckhuysen BM (2010) The catalytic valorization of lignin for the production of renewable chemicals. Chem Rev 110(6):3552-3599

Publisher's Note Springer Nature remains neutral with regard to jurisdictional claims in published maps and institutional affiliations. 